Article

\title{
Regional Evaluation of Fungal Pathogen Incidence in Colombian Cocoa Crops
}

\author{
Raquel Villamizar-Gallardo ${ }^{1, *}$, Johann F. Osma ${ }^{2}\left(\mathbb{C}\right.$ and Oscar Orlando Ortíz-Rodriguez ${ }^{3(\mathbb{C})}$ \\ 1 Interdisciplinary Laboratory of Nanotechnology and Sustainable Management, NANOSOST-UP, \\ Department of Microbiology, School of Basic Sciences, Universidad de Pamplona, Km 1 vía Bucaramanga, \\ Pamplona 543050, Colombia \\ 2 CMUA, Department of Electrical and Electronic Engineering, Universidad de los Andes, Cra. 1E \# 19A-40, \\ Bogota 1100111, Colombia; jf.osma43@uniandes.edu.co \\ 3 Department of Industrial Engineering, School of Engineering and Architecture, Universidad de Pamplona, \\ Km 1, vía Bucaramanga, Pamplona 543050, Colombia; oscarortiz@unipamplona.edu.co \\ * Correspondence: raqvillamizar@unipamplona.edu.co; Tel.: +57-3172409802
}

Received: 17 July 2018; Accepted: 11 December 2018; Published: 4 March 2019

\begin{abstract}
The production of cocoa (Theobroma cacao L.) in Colombia has a significant environmental and socioeconomic importance as a promissory crop in the post-conflict process. The department of Norte de Santander has cocoa crops that are dramatically affected by fungal pathogens causing important losses during harvest and post-harvest. Therefore, the current study focused on the determination of the incidence of diseases caused by phytopathogenic fungi in cocoa crops, and the identification of primary phytopathogenic fungi found in biological material from different farms of the region. The study was conducted in four municipalities of the department, by sampling fruits infected with frosty pod rot (FPR) and black pod rot (BPR) that presented in situ incidence ranging from 0.37 to $21.58 \%$ and from 1.75 to $35.59 \%$, respectively. The studied hybrid materials, together with clone TSH 65, were found to be the most susceptible, while the remaining clones were more tolerant, especially CCN 51, IMC 67, and ICS95. Fifteen strains were isolated using in vitro assays and then morphologically characterized both in solid media and by microscopy. Nine of them corresponded to the pathogen Moniliophthora roreri, and other six to Phytophthora palmivora. The isolated agents showed in vitro morphological variability, as well as the ability to adapt to different environments when growing in situ.
\end{abstract}

Keywords: cocoa; fungi; incidence; phytopathogenic diseases

\section{Introduction}

Pathogenic fungi are a significant threat to global food security that generate losses in plant production equivalent to 200 billion dollars per year estimated in losses of more than $30 \%$ of the harvest; however, without the use of the actual crop protection methods, its impact would increase [1,2].

Cocoa (Theobroma cacao L.) trees house a diverse pathogenic community [3], so controlling methods for cocoa pathogens are required. Currently, the phenomena of El niño and La niña produce considerable alternation between dry and rainy periods, thus intervening in the productive and vegetative cycles of the cocoa trees [4] and promoting fungal pathogens infection [5].

Phytopathogenic diseases cause 30 to $100 \%$ annual losses of the cocoa harvest [6]. Frosty pod rot (FPR), caused by the endemic fungus Moniliophthora roreri (Cif. \& Par.) Evans (1986), is one of the most severe diseases affecting cocoa not only in Colombia but also in some Central and South American countries. It takes about 74 days for the symptomatology to start, with shiny humps or swellings until a white fungus structure formation covers the pod and spreads to contaminate others pods [7]. 
Another very frequent disease of cocoa crops is known as black pod rot (BPR), which is produced by different species of Phytophthora. It is featured by the presence of lesions that start with a light color and finally become chocolate brown. After two or three weeks, these lesion cover the entire pod, starting at the apex and finishing at the peduncle [4].

The principal worldwide cocoa growing regions are Africa, Asia, and Latin America, with Ivory Coast of Africa encompassing 33\% of the global supply. According to FAOSTAT, Ivory Coast was the largest producer worldwide in 2015, with 2,176,960 tons, followed by Ghana (740,000 tons) and Indonesia (395,500 tons). Latin America not only accounts for the $14.4 \%$ of the global cocoa production (522,000 tons) but also grows 70\% of the global fine aromatic cocoa, mainly in Ecuador, Colombia, Peru, and Venezuela [8].

Colombian production was about 26,104 tons in 2015 and 33,443 tons in 2016, thus generating an average six-monthly growth rate of $12 \%$. Locally, the department of Santander contributes about $50 \%$ of the national production, while the neighboring department of Norte de Santander contribution corresponds to $4 \%$. As part of the Colombian Ten Years Cocoa Growing Development Plan 2012-2021, the national goal is to produce 246,000 tons in 2021, requiring an investment of US 1100 million in the next 10 years [9].

Therefore, considering that the majority of biological materials planted in the Norte de Santander region are susceptible to fungal pathogenic agents, the main objective of this study was to establish the present in situ incidence of FPR and BPR, and to isolate and characterize their causal agents in vitro, evaluating different biological materials planted in four farms of Norte de Santander, thus contributing to the current knowledge of the agro-ecology of this crop to develop better cocoa pathogen control strategies.

\section{Materials and Methods}

\subsection{Study Area}

The study was carried out in four randomly selected farms located at the municipalities of Bochalema $\left(7^{\circ} 39^{\prime} 15.15^{\prime \prime} \mathrm{N}, 72^{\circ} 37^{\prime} 4.52^{\prime \prime} \mathrm{W}\right)$, Bucarasica $\left(7^{\circ} 53^{\prime} 04.5^{\prime \prime} \mathrm{N}, 72^{\circ} 42^{\prime} 12.6^{\prime \prime} \mathrm{W}\right)$, Chinacota $\left(7^{\circ} 35^{\prime} 27.28^{\prime \prime} \mathrm{N}, 72^{\circ} 37^{\prime} 34.55^{\prime \prime} \mathrm{W}\right)$ and Zulia $\left(8^{\circ} 11^{\prime} 49.55^{\prime \prime} \mathrm{N}, 72^{\circ} 34^{\prime} 34.95^{\prime \prime} \mathrm{W}\right)$, all of them from the Department of Norte de Santander, Colombia. Evaluated sites have a warm and humid climate, with a temperature range from $22{ }^{\circ} \mathrm{C}$ to $31^{\circ} \mathrm{C}$, with an average of $28.6^{\circ} \mathrm{C}$ and altitudes ranging from 220 to $1051 \mathrm{~m}$ a.s.l. Annual mean rainfall is $1969.6 \mathrm{~mm}$, allowing the zone to be classified as a tropical humid forest, and an average cocoa production of around 1600 tons per year [10].

\subsection{Soil Sample Collection}

Ten soil samples of $100 \mathrm{~g}$ each were taken from the rhizosphere of the plants at $20 \mathrm{~cm}$ of depth, over an area of 1 ha of cultivated land, until collecting $1 \mathrm{~kg}$ of soil sample from each farm. Samples were packed and transported to the Soil Laboratory of the Chemistry Department of the Universidad Industrial de Santander, Colombia, where they were analyzed for $\mathrm{C}, \mathrm{Ca}, \mathrm{Mg}, \mathrm{K}$, and $\mathrm{P}$ content and $\mathrm{pH}$. Texture was characterized by electrometric methods and through colorimetric and atomic absorption [11,12].

\subsection{Fungal Incidence}

Fungal incidence was evaluated by analyzing the number of pods affected by the disease. Therefore, incidence was measured as the percentage of diseased fruits (with internal and external symptoms) out of all harvested fruits. The procedure was carried out in the field, by sampling $10 \%$ of the total population in 1 ha of cocoa crop. The percentage of incidence was calculated as the percentage ratio between the number of diseased pods (D) and the total number of pods-diseased (D) plus healthy $(\mathrm{H})$ pods_-in the sampled population (Equation (1)).

$$
\% \text { Incidence }=\left(\frac{\mathrm{D}}{\mathrm{D}+\mathrm{H}}\right) \times 100 \%
$$




\subsection{Pod Sample Collection}

For the pod collection, 10 pods with FPR and BPR, respectively, from the different available cocoa materials in the plantations (clones and hybrids) were collected. Diseased pods exhibited typical symptoms of each of the above-mentioned diseases. The collected pods were packed in plastic, labeled, and transported in boxes to the laboratory of Nanosost (Nanotechnology and Sustainable Research Group at the Universidad de Pamplona, Pamplona, Colombia) for later analysis [6].

\subsection{Fungal Isolation and Cultures}

Phytopathogens were obtained from cocoa pods exhibiting the symptoms of each disease. Spores present in the upper and inner pod cortex were directly cultured on petri dishes containing potato dextrose agar modified with cocoa pod cortex extract and chloramphenicol (CEC-PDA) [6]. Isolated colony forming unit were re-cultured until obtaining axenic colonies, which were subsequently characterized.

\subsection{Macroscopic Morphology Characterization}

Macroscopic morphological characterization was carried out in CEC-PDA taking into consideration aspects such as texture, edge, the presence or absence of rings, and mycelium color, as described in [13] with some modifications. Mycelium color was determined according to the Munsell color chart [14]. The growth rate was assessed by measuring the diameter of the colonies in Moniliophthora and Phytophthora. This was determined with an incubation period of 18 days at $25^{\circ} \mathrm{C}$ during which radial growth was monitored every two days by using ImageJ software (National Institutes of Health, Bethesda, Maryland). All assays were conducted in triplicate.

\subsection{Microscopic Morphology Characterization}

Microscopic morphology characterization was carried out by washing the colonies and staining with lactophenol blue, safranin, and/or lugol. In the case of Phytophthora, the length and width of the sporangia and zoospores were measured by adding sterile distilled water at $4{ }^{\circ} \mathrm{C} / 2 \mathrm{~h}$ to separate the sporangium [15]. For Moniliophthora, the length and width of individual spores and chain spores, taking into consideration the presence and/or absence of globose and ellipsoidal spores, were measured. A photographic record was obtained with a Nikon Eclipse 80i phase contrast optical microscope $(1000 \times$ magnification, Sanitas Ltd.a, Bogota, Colombia) and then analyzed in ImageJ software. At least 15 zoospores and spores were measured per isolated strain.

\subsection{Statistical Analysis}

Statistical analysis was used to classify the characterization of the fungal samples. Different types of descriptive components were used in these analyses, some univariate and other multivariate. Univariate components considered the prevalence of the pathogenic fungi in the sampled farms, while multivariate components included a series of dichotomous qualitative variables associated with colony color, texture, edge, and the presence or absence of rings. These multivariate analyses were used to classify and to establish evaluation groups using Ward's grouping method [16].

Spore length and width $(\mu \mathrm{m})$ were determined using a multivariate analysis applied to the variance of 75 observations generated in the study. For such a purpose, two levels were considered as the factor under analysis, which was carried out under and a completely randomized factorial design. After this, a second multivariate analysis was applied to the variance data, this time segregating not only the type, using five experimental units per isolate. The factorial design remained the same, only changing the number of levels involved. For this analysis, a table of mean values adjusted through least squares was obtained under Wilks' lambda test. In a similar way, size in terms of average length and width $(\mathrm{cm})$ of each isolate (nine of them correspond to M. roreri, and six to P. palmivora) was determined via multivariate analysis. 
Growth rate was assessed by adjusting specific curvilinear regression models to colony length and width data that were collected every two days. The rate of change for each model, which depended on the evaluation day in all cases, was calculated as the first derivative. In each case, both length and width data allowed for grouping the isolates. By equating the estimated curves, it was possible to calculate the point at which a given length or width growth rate overtook a group of isolates of the same pathogen genus. Using all this information obtained from the statistical analysis, it was possible to group the different samples, the statistical prevalence of the pathogenic fungi, and to determine their growth rates, morphological characteristics, and therefore their identification.

\section{Results}

\subsection{Soil Sample Collection}

The soil analysis results showed that soil $\mathrm{pH}$ values in the towns of Zulia and Bucarasica are slightly acidic, while those of Bochalema and Chinacota tend to be more neutral, as also reported in [17]. As for $C$ content, the samples from the municipality of Zulia showed the lowest counts, while those of Bochalema were the highest. The $\mathrm{Ca} / \mathrm{Mg}$ ratio oscillated within a 3.2-3.6 range, which is considered acceptable, while the $(\mathrm{Ca}+\mathrm{Mg}) / \mathrm{K}$ ratio, especially in Bochalema soils, was found to be below the acceptable range, with a value of 17.7 (Table 1).

Table 1. Physicochemical characteristics of the soils employed for cocoa growing in the study area.

\begin{tabular}{cccccccccc}
\hline Location & $\begin{array}{c}\mathbf{T} \\
\left.\mathbf{(}{ }^{\circ} \mathbf{C}\right)\end{array}$ & $\begin{array}{c}\mathbf{R H} \\
\mathbf{( \% )}\end{array}$ & $\begin{array}{c}\text { Altitude } \\
\mathbf{( m} \text { a.s.1.) }\end{array}$ & $\mathbf{p H}$ & $\mathbf{\%} \mathbf{C}$ & $\mathbf{P}(\mathbf{p p m})$ & $\mathbf{C a : M g}$ & $\mathbf{( C a / M g )}+\mathbf{K}$ & Texture \\
\hline Bochalema & 23.0 & 63 & 1051 & 5.6 & 1.8 & 49.4 & 3.6 & 17.7 & Sandy \\
Bucarasica & 31.0 & 70 & 870 & 5.1 & 2.1 & 6.0 & 3.6 & 27.0 & Sandy-clay \\
Chinacota & 22.7 & 86 & 1200 & 5.9 & 2.1 & 53.8 & 3.2 & 30.0 & Sandy-loam \\
Zulia & 30.0 & 66 & 220 & 5.3 & 2.5 & 28.0 & 3.4 & 29.9 & Clay loam \\
\hline
\end{tabular}

$\mathrm{RH}$, relative humidity; \% C, carbon content.

\subsection{Pod Sample Collection}

Random collected pods with FPR and BPR from the different plantations sites were analyzed to establish the agro-ecological characteristics of the evaluated areas. Incidence of FPR in the four sites ranged from 0.4 to $21.6 \%$, while BPR ranged from 1.8 to $35.6 \%$. The most susceptible biological materials, to both FPR and BPR, were Hybrid_1 and Hybrid_2, followed by clone TSH 565 . The lowest incidence percentages were observed in clones CCN 51, ICS 95, and ICM 67 (Figure 1).

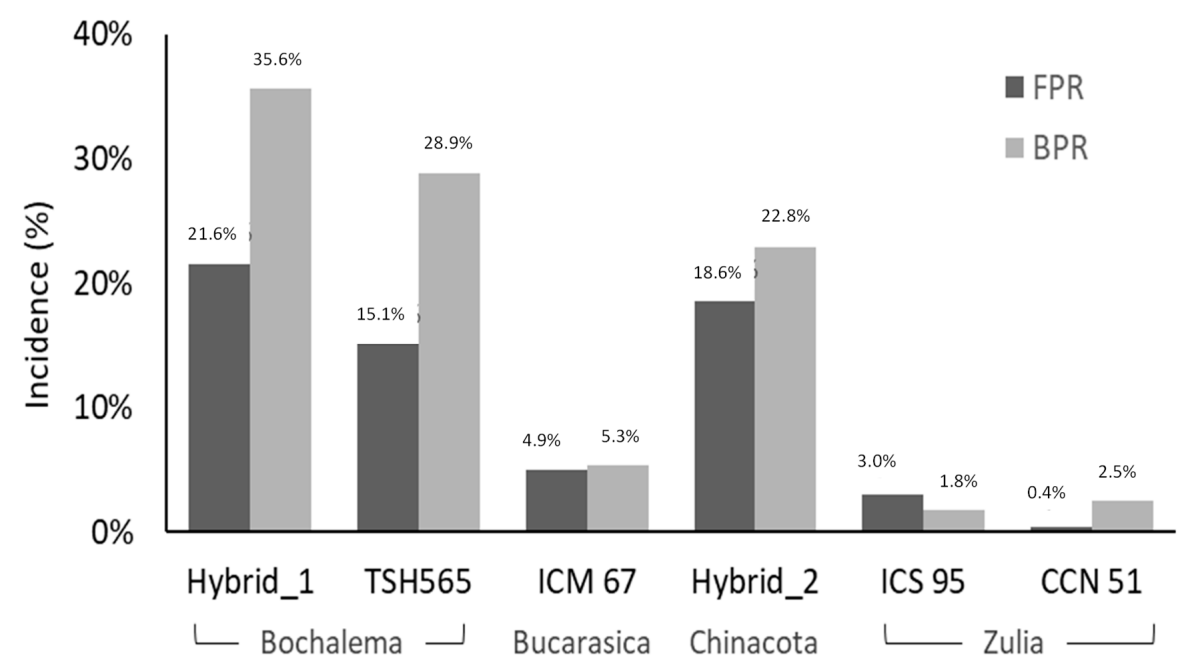

Figure 1. Frosty pod rot (FPR) and black pod rot (BPR) incidence in the study area. 


\subsection{Fungal Isolation and Cultures}

For the fungal isolation and cultures, a total of 24 phytopathogens were identified in the studied biological material by their morphological characteristics. Macroscopically, nine of them were characterized as Moniliophthora, and six as Phytophthora, thus coinciding with the results obtained in $[13,14,17]$. Secondary pathogens like Aspergillus and Fusarium were also commonly found; however, this study focused only on the primary pathogens found (i.e., Moniliophthora and Phytophthora) (Table 2).

Table 2. Frequency of phytopathogenic fungi isolated from the different cocoa biological materials.

\begin{tabular}{ccccccc}
\hline \multirow{2}{*}{ Biological Material } & \multicolumn{2}{c}{ Analyzed Pods } & \multicolumn{3}{c}{ Commonly Isolated Phytopathogens } \\
\cline { 2 - 7 } & FPR & BP & Moniliophthora & Phytophthora & Aspergillus & Fusarium \\
\hline Hybrid_1 & 10 & 10 & 4 & 2 & 2 & 1 \\
Hybrid_2 & 10 & 10 & 1 & 3 & 1 & 3 \\
ICS 95 & 10 & 10 & 1 & 0 & 0 & 1 \\
ICM 67 & 10 & 10 & 1 & 0 & 0 & 0 \\
CCN 51 & 10 & 10 & 1 & 0 & 0 & 0 \\
TSH 656 & 10 & 10 & 1 & 1 & 1 & 0 \\
\hline Total & 60 & 60 & 9 & 6 & 4 & 5 \\
\hline
\end{tabular}

FPR: frosty pod rot, BP: black pod.

\subsection{Macroscopic Morphology Characterization}

Differences in both morphology and growth characteristics were observed in the isolates of Moniliophthora. The pathogens exhibited a plushy texture with central and/or terminal rings (Figure 2A), as also reported in [13]. Munsell colors are similar to those reported in [18] In turn, Phytophthora exhibited a uniform color in the culture medium, as reported in [19]. In addition, sharp edges with no ring formation were observed (Figure 2B).

A

A Moniliophthoraspp.

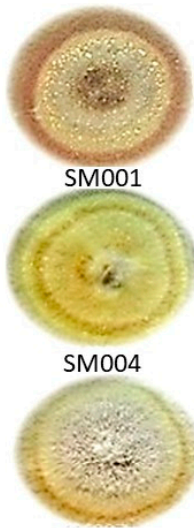

SM007

B



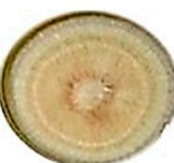

SM002

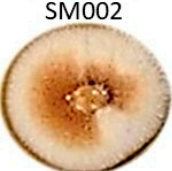

SM005

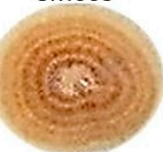

SM008

Phytophthoraspp.

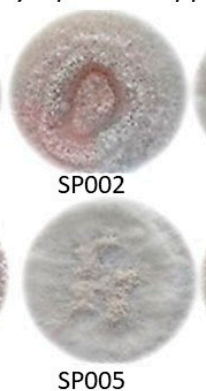

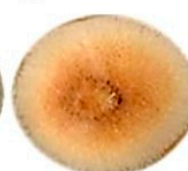

SM003

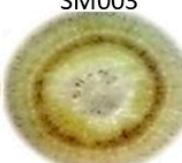

SM006

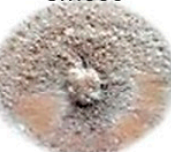

SM009

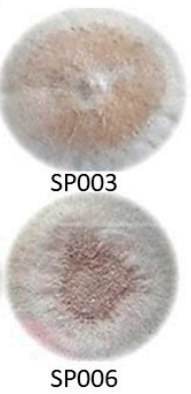

Code

$5 \mathrm{YR}-5 / 3 ; 5 \mathrm{YR}-8 / 1$

$5 \mathrm{YR}-6 / 3 ; 5 \mathrm{YR}-8 / 2 ; 5 \mathrm{YR}-8 / 3$

$7.5 \mathrm{YR}-\mathrm{N} 8 ; 7.5 \mathrm{YR}-8 / 2$

$7.5 \mathrm{YR}-\mathrm{N} 8 ; 7.5 \mathrm{YR}-8 / 4$

$7.5 \mathrm{YR}-\mathrm{N} 8 ; 7.5 \mathrm{YR}-8 / 4$

$2.5 \mathrm{Y}-5 / 4 ; 2.5 \mathrm{Y}-8 / 6 ; 10 \mathrm{YR}-6 / 6 ; 10 \mathrm{YR}$

$2.5 \mathrm{Y}-8 / 4 ; 10 \mathrm{YR}-5 / 8 ; 10 \mathrm{YR}-7 / 1 ; 10 \mathrm{YR}-7 / 9 ; 10 \mathrm{YR}-8 / 1$

$2.5 \mathrm{Y}-8 / 4 ; 10 \mathrm{YR}-5 / 8 ; 10 \mathrm{YR}-7 / 1 ; 10 \mathrm{YR}-7 / 6 ; 10 \mathrm{YR}-8 / 4$

$2.5 \mathrm{Y}-8 / 4 ; 2.5 \mathrm{Y}-8 / 6 ; 5 \mathrm{YR}-6 / 6 ; 5 \mathrm{YR}-7 / 6 ; 5 \mathrm{YR}-8 / 4$

Figure 2. Macroscopic growth and Munsell Colors of (A) Moniliophthora (SM01-SM009) and (B) Phytophthora (SP001-SM006) in agar. CEC-PDA, cocoa pod cortex extract and chloramphenicol. 
Figure 3 shows the growth rate measurements observed every two days over an 18-day period for all Moniliophthora and Phytophthora isolates. When analyzing the results obtained for Moniliophthora spp. isolates, two groups can be clearly distinguished. The first group (i.e., SM001 to SM005) displayed lower growth rates than the second group (i.e., SM006 to SM009). Isolates SM006 to SM009 were observed to be the longest ones, reaching diameters between 4.0 and $4.5 \mathrm{~cm}$ after 18 days of incubation. The first group was isolated from pods coming from Hybrid_2, clones ICM 67, CCN51, ICS 95, and TSH 656, while isolates SM0006 to SM009 were all obtained from Hybrid_1.

Phytophthora isolates also formed two groups: SP001 to SP003 and SP004 to SP006. The first one came from clones TSH and Hybrid_1, while the second group came from Hybrid_2. The growth rates of the first group were lower than those of the second group. The two higher growth rates correspond to isolates SP004 and SP005. The total diameter of the area covered by the first group ranged between 2.2 and $3.1 \mathrm{~cm}$, while the second group reached 3.8 to $4.5 \mathrm{~cm}$ on Day 18 of the trial.
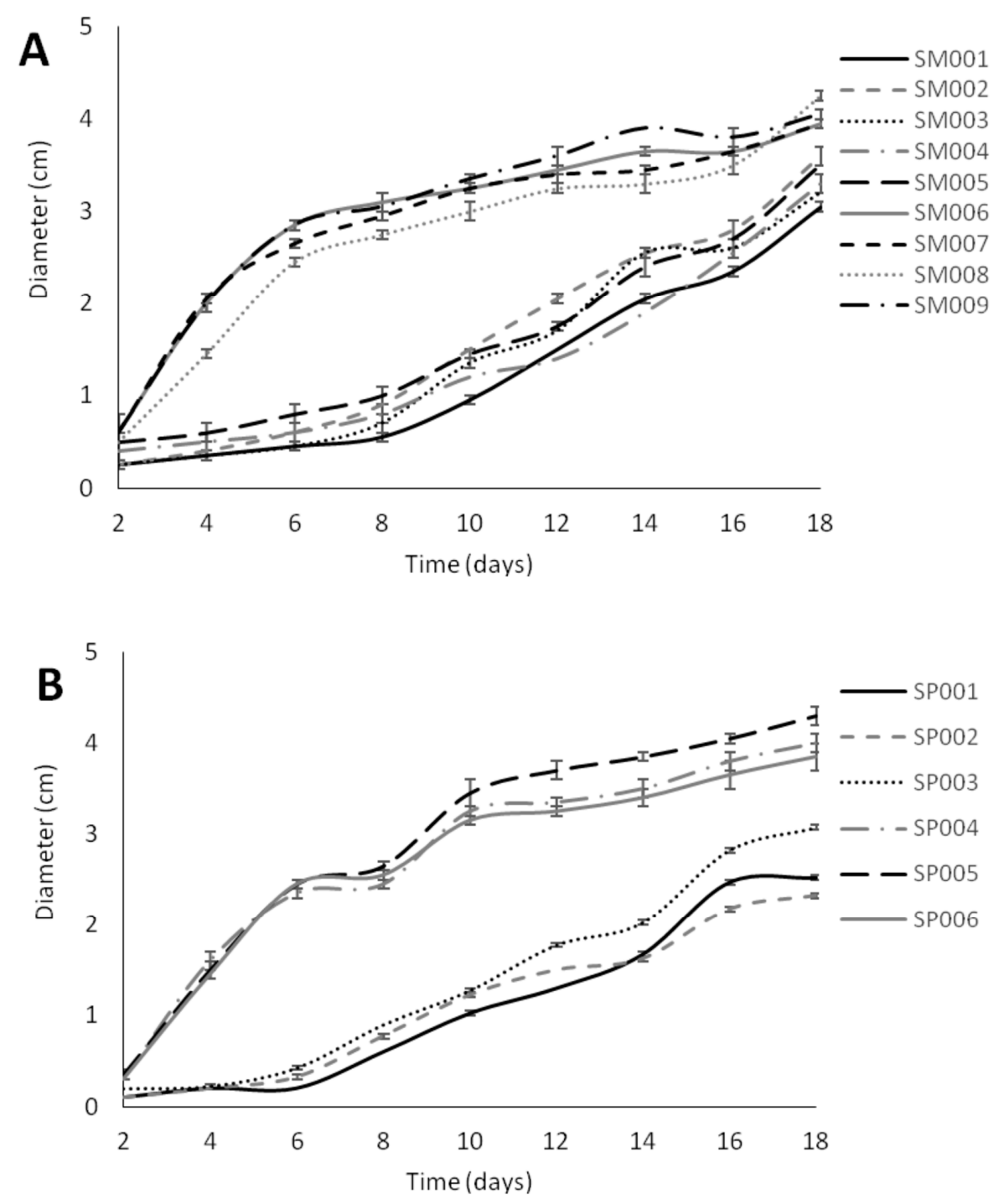

Figure 3. Diameter (cm). (A) Nine isolates of Moniliophthora (B). Six isolates of Phytophthora. 
The average growth rate of Moniliophthora in the first group ranged from $0.3 \mathrm{~cm}$ on Day 2 to $3.3 \mathrm{~cm}$ in Day 18, while for the second group growth ranged between $0.4 \mathrm{~cm}$ on Day 2 and $4.3 \mathrm{~cm}$ on Day 18 . These results agree with Lozada et al. (2012) [20], who determined a radial growth in PDA agar of 3.7 and $4.5 \mathrm{~cm}$. Both Group 1 and Group 2 increased 10 times in size over the 18 days of incubation. Isolates from Group 2 significantly increased their growth rate after 4 days of incubation; however, isolates of Group 1 required at least 8 days to significantly increase its growth rate.

Phytophthora Group 1 showed an average growth of $0.15 \mathrm{~cm}$ on Day 2 and $2.6 \mathrm{~cm}$ at the end of the incubation period with an increase of 25 times in its initial size, with the highest growth rate observed on the 8th day. Group 2 presented an initial growth of $0.35 \mathrm{~cm}$ with a final diameter of $4 \mathrm{~cm}$, covering almost the entire petri dish. This represented an increase of 10 times its initial size, showing that isolates belonging to this group required only 4 days of incubation, similar to the results reported in [19]. In addition, $24 \mathrm{~h}$ photoperiods were necessary to promote the growth of the Phytophthora group. Finally, isolates of Moniliophthora as well as Phytophthora that showed the highest growth rates were isolated from biological material of unknown hybrid parentage.

\subsection{Microscopic Morphology Characterization}

Microscopically, Moniliophthora showed hyaline, septate hyphae with branched conidiophores from which catenulate, ellipsoid, or circular conidia were obtained, exhibiting basipetal maturation (Figure 4) as also described in [4]. These findings allowed one to determine that the species of Moniliophthora isolated in all cases corresponded to Moniliophthora roreri [13]. Single spores showed an average length/width ratio of 1.0 to 2.3, globose/subglobose being more common than ellipsoidal, which is consistent with a previous report in [19]. Chain spores showed a length/width ratio in the range from 0.72 to 1.04 (Figure 5).

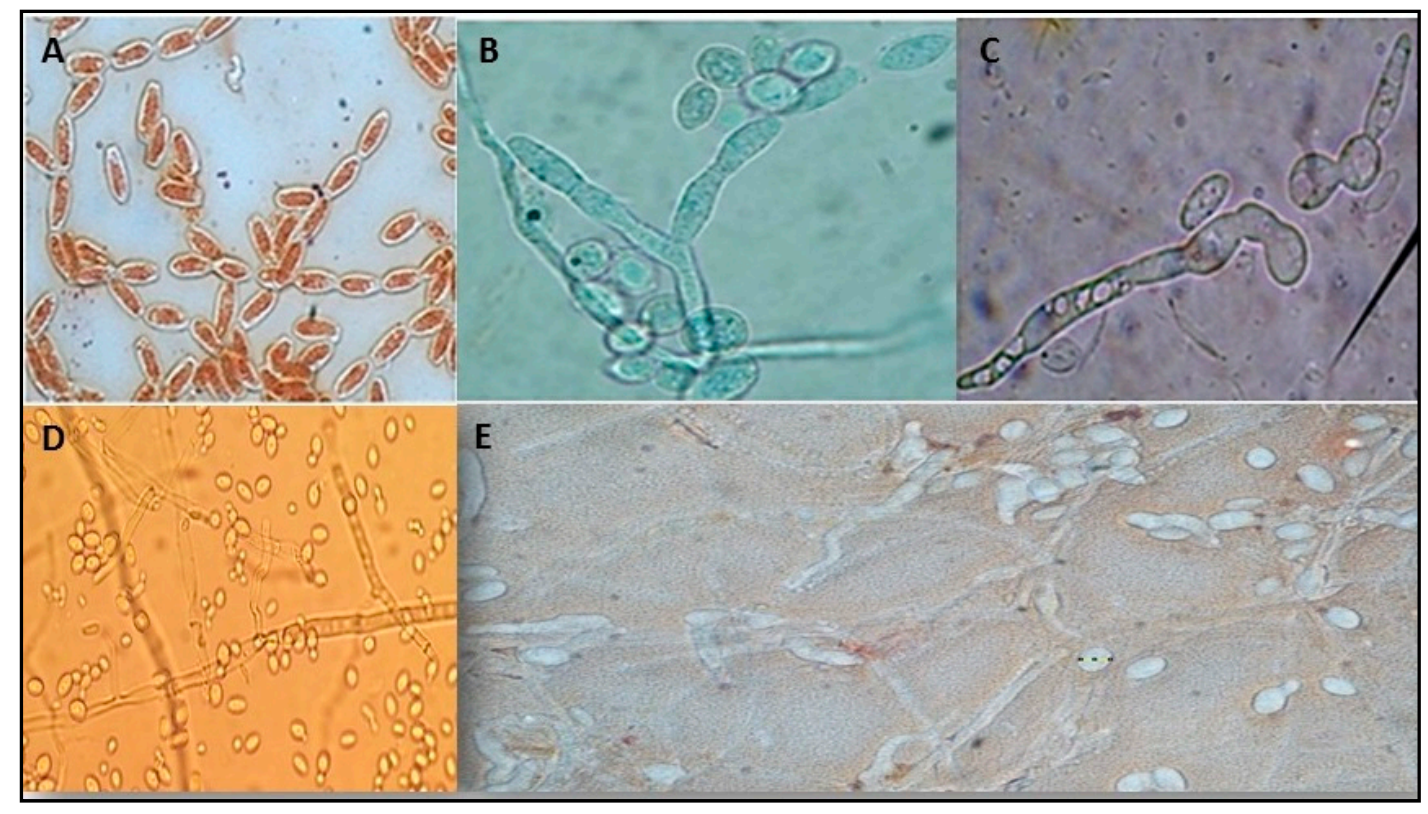

Figure 4. Reproductive structures of isolated Moniliophthora roreri $(100 \times)$. (A) Catenulate spores. (B,C) Basipetally maturing spores. (D) Globose and ellipsoid spores. (E) Hyaline hyphae and ellipsoid spores. 
A

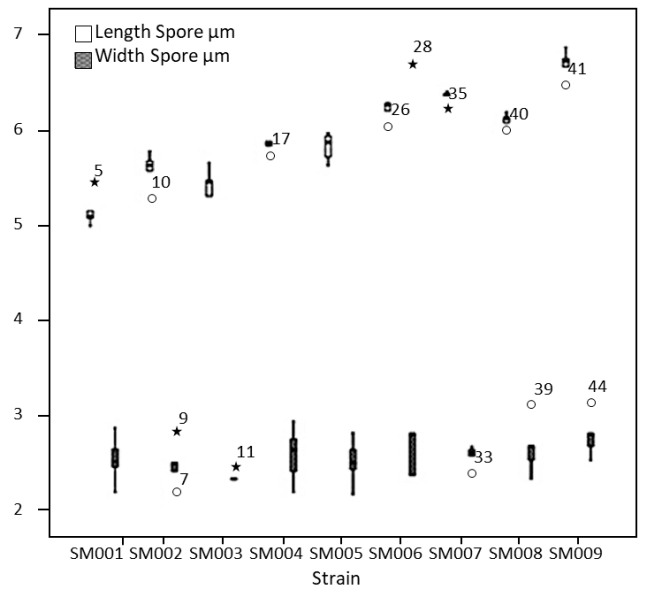

B



Figure 5. Average size of individual and chain spores of Moniliophthora roreri. (A) Spore size and (B) length and width.

Isolated pathogens revealed a fast growth when favored by the cocoa supplement in the culture medium. This is consistent with a previous report in [21], wherein it was shown that media modified with cocoa favor the growth of Moniliophthora perniciosa. Group 2 underwent less than $48 \mathrm{~h}$ growth rates, accelerated from the 4th day of incubation. Morphologically, it was possible to observe that isolates showed no significant differences between them, except for the diversity of colors found in M. roreri mycelium. These results are similar to those reported in [18].

Phytophthora showed thin, non-septated (coenocytic), hyaline mycelium with papillate sporangia containing zoospores (Figure 6), thus coinciding with the results obtained in [14]. The predominant morphology was that of ovoid, papillate sporangia with short pedicels. Sporangia had an average length of $33.46 \mu \mathrm{m}$ and width of $31.93 \mu \mathrm{m}$ (Figure 7A), while zoospores showed an average length/width ratio of 2.71 (Figure 7B). These findings indicated that the species of Phytophthora isolated in all cases corresponded to Phytophthora palmivora [22].

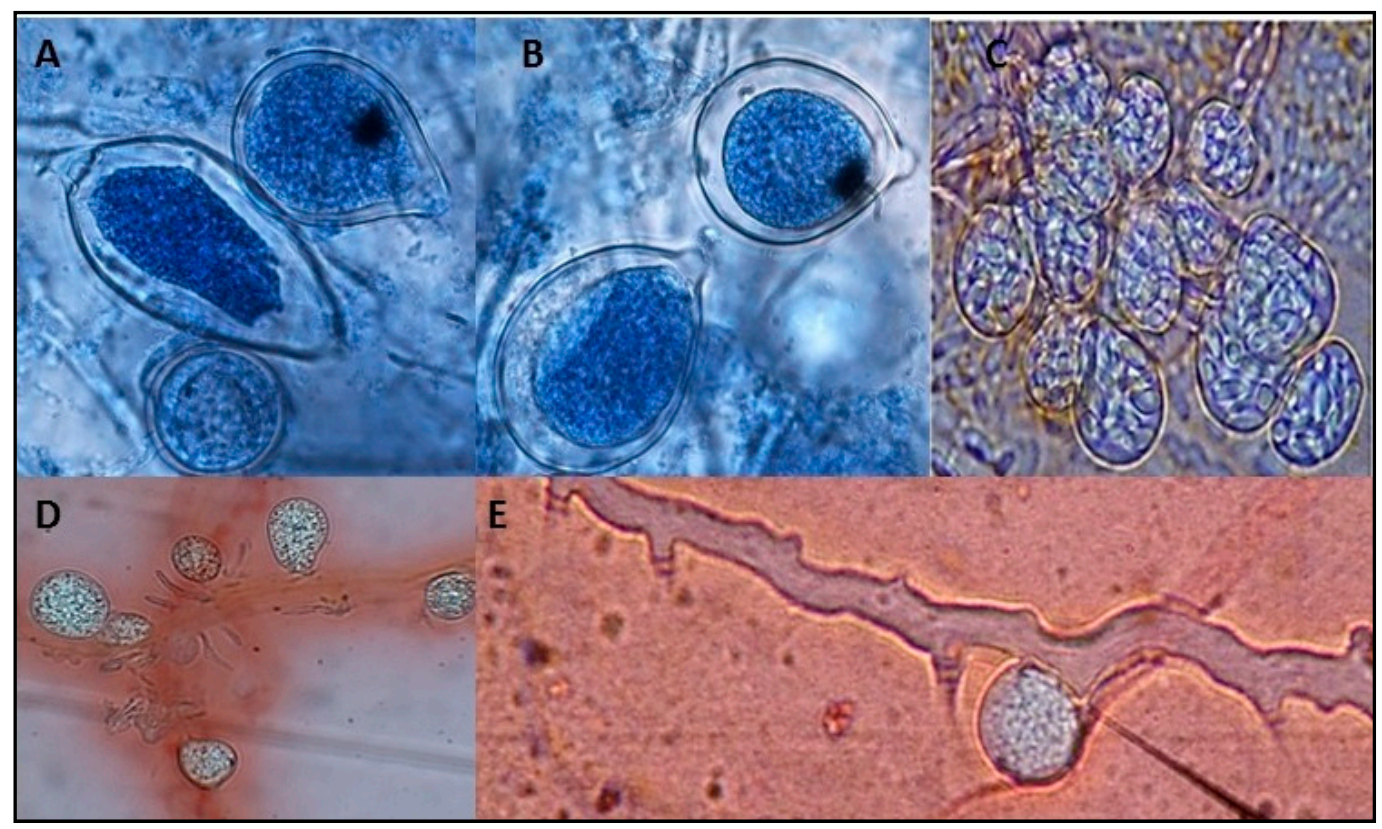

Figure 6. Reproductive structures of isolated Phytophtora palmivora $(40 \times)$. (A) Ovoid sporangia. (B) Papillate zoosporangia with short pedicels. (C,D) Zoosporangia containing mobile zoospores.

(E) Zoosporangium sprouting from a coenocytic hypha. 
A



B

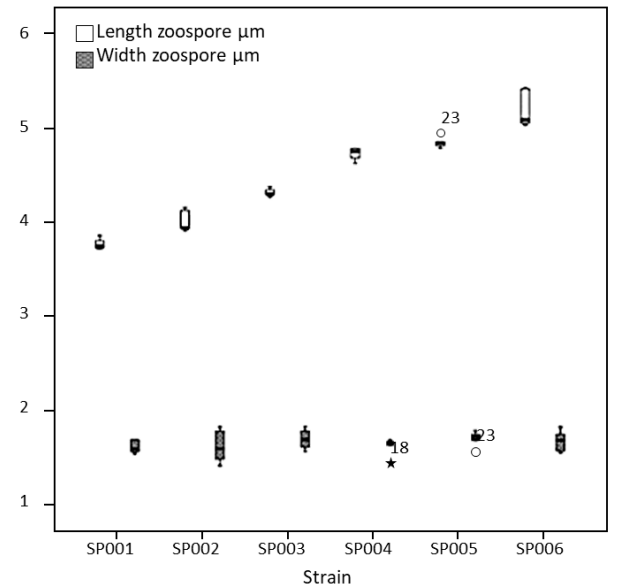

Figure 7. Average size of (A) sporangia and (B) zoospores of Phytophtora palmivora.

\section{Discussion}

Proper soil composition is required for cocoa crops. A low $(\mathrm{Ca}+\mathrm{Mg}) / \mathrm{K}$ ratio produce immature plants, which facilitates pathogen attack. This was observed in Bochalema soil samples, so the highest incidence of phytopathogenic diseases was also observed in that locality.

Soil texture varied from sandy loam, through sandy-clay to clay-loam. The latter two soil types are very permeable to water, which facilitates the attack of pathogens, especially at the root level. This characteristic condition increased susceptibility to pathogen attack in Chinacota and Bochalema. However, a low incidence of plant pathogens was observed in the municipality of Bucarasica, which may be due to the resistance of the biological material employed there. Clone ICM 67 has shown resistance to attack by pathogens in both root and stem [23].

In the evaluated farms, the crops are established from 220 to $1200 \mathrm{~m}$ a.s.l., thus corresponding to physiographic cocoa conditions which are found to be between 30 and $1300 \mathrm{~m}$ a.s.l. Incidence and severity of moniliasis decreases above $800 \mathrm{~m}$ a.s.l., coinciding with an increasing susceptibility to black pod [24]. This was evident in the farms located in Zulia and Bucarasica, where the incidence of these two diseases was observed to be the lowest. On the contrary, the farms located in Chinacota and Bochalema, above $1000 \mathrm{~m}$ a.s.l., showed an increased incidence of black pod, coupled to a decrease of moniliasis.

Cocoa cultivation shows an optimum development at temperatures ranging between 23 and $30{ }^{\circ} \mathrm{C}$, an upper limit that should never exceed [25]. In this regard, all the evaluated farms are within the appropriate range. However, in the towns such as Chinacota and Bochalema, considerable day/night temperature differences were observed $\left(\sim 5-7^{\circ} \mathrm{C}\right)$ compared to others studied localities. This abrupt change in temperature favors the germination of pathogen spores such as Phytophthora palmivora and Moniliopthora roreri, thus supporting the high incidence of these pathogens in two locations. In addition, cocoa crops in this department usually resort to plantain as a natural shadowing system. These, coupled to the annual precipitation range in the studied localities, increases the incidence of diseases caused by phytopathogens. Thus, environmentally speaking, when cocoa is grown under the shade of other trees, carbon sink and biodiversity are both favored. Moreover, there is availability of cocoa varieties yielding up to $1500 \mathrm{~kg} / \mathrm{ha}$, which, compared to the $300 \mathrm{~kg} / \mathrm{ha}$ records of the local varieties, are considerably more efficient because they use the same amount of green water (rainfall) to produce significantly higher yields [11,26].

In situ results determined that hybrid materials were the most pathogen susceptible, together with clone TSH 65, while the most tolerant materials corresponded to clones CCN 51, IMC 67, and ICS 95. The last one has been found to resist aggressive strains of M. roreri [27], while clone IMC 67 is moderately resistant to the frosty pod rot since it is able to reduce the sporulation process of the fungus [7]. 
Studies published by the Colombian Federation of Cocoa Growers revealed that farmers prefer clones ICS 95 and CCN 51, which yield 1561 and $1532 \mathrm{~kg} /$ ha per year, respectively, and exhibit a low incidence of moniliasis [26].

\section{Conclusions}

The current research determined that cocoa crops in Norte de Santander are affected by both FPR and BPR, the first one being more significant than the latter, especially in the studied municipalities of Bochalema and Chinacota, due to the type of biological material planted. The hybrid materials, together with clone TSH 65 , were found to be the most susceptible, while the remaining clones exhibited higher tolerance, especially CCN 51, IMC 67, and ICS 95. Therefore, it is recommended that these resistant materials are spread, especially to those cocoa growers who do not belong to FEDECACAO, in order to avoid the incidence of phytopathogens in the region and increase cocoa productivity. However, for those growers cropping aromatic cocoa clones, which are usually susceptible to different pathogens, cultural practices will be the best option to keep the crops safe.

Author Contributions: R.V.-G.: design, data analysis, and test performance; J.F.O.: new reagents/analytic tools; O.O.O.-R.: writing.

Funding: To the Colombian Administrative Department of Science, Technology, and Innovation COLCIENCIAS (Project Reference 0371-2012); Inter-American Development Bank (IDB); World Bank (WB) BIRT for the fully financial support.

Conflicts of Interest: The authors declare no conflict of interest. The founding sponsors had no role in the design of the study; in the collection, analyses, or interpretation of data; in the writing of the manuscript; or in the decision to publish the results.

\section{References}

1. Kumar, M.; Brar, A.; Yadav, M.; Chawade, A.; Vivekanand, V.; Pareek, N. Chitinases-Potential candidates for enhanced plant resistance towards fungal pathogens. Agriculture 2018, 8, 88. [CrossRef]

2. Horbach, R.; Navarro-Quesada, A.R.; Knogge, W.; Deising, H.B. Sustainable agricultural mechanization for smallholders: What is it and how can we implement it? Agriculture 2017, 7, 50. [CrossRef]

3. Tand, D.S.; Leong, R.N.; Laguna, A.F.; Ngo, C.A.; Lao, C.A.; Amalin, D.M.; Alvindia, D.G. AuToDiDAC: Automated tool for disease detection and assessment for cacao black pod rot. Crop Prot. 2018, 103, $98-102$. [CrossRef]

4. Naranjo-Merino, C.A.; Ortíz-Rodriguez, O.O.; Villamizar-G, R.A. Assessing green and blue water footprints in the supply chain of cocoa production: A case study in the Northeast of Colombia. Sustainability 2018, 10, 38. [CrossRef]

5. Villamizar-G, R.A.; Cruz, J.F.O.; Ortíz-R, O.O. Fungicidal effect of silver nanoparticles on toxigenic fungi in cocoa. Pesqui. Agropecuria Bras. 2016, 51, 1929-1936. [CrossRef]

6. Villamizar-G, R.A.; Ortíz-Rodriguez, O.O.; Escobar, J.W. Symbiotic and endophytic fungi as biocontrols against cocoa (Theobroma cacao L.) phytopathogens. Summa Phytopathol. 2017, 43, 87-93. [CrossRef]

7. Cubillos, G. Frosty pod rot, disease that affects the cocoa (Theobroma cacao) crops in Colombia. Crop Prot. 2017, 96, 77-82. [CrossRef]

8. Safaiefarahani, B.; Mostowfizadeh-Ghalamfa, R.; Cooke, D. Characterization of Phytophthora inundata according to host range, morphological variation and multigene molecular phylog. Phytopathol. Mediterr. 2013, 52, 46-65. [CrossRef]

9. Ortíz-Rodriguez, O.O.; Villamizar-G, R.A.; Rangel, M. Applying life cycle management of Colombian Cocoa production. Food Sci. Technol. 2014, 34, 62-68. [CrossRef]

10. García-Cáceres, R.; Perdomo, A.; Ortíz-Rodriguez, O.O.; Beltrán, P.; López, K. Characterization of the supply and value chains of Colombian cocoa. DYNA 2014, 81, 30-40. [CrossRef]

11. Eckert, D.; Sims, J.T. Recommended soil pH and lime requirement tests. In Northeast Regional Bulletin \#493, 3rd ed.; Sims, J.T., Wolf, A., Eds.; Agricultural Experiment Station, University of Delaware: Newark, DE, USA, 2011; pp. 19-25. 
12. Wolf, A.M.; Beegle, D.B. Recommended soil tests for macronutrients. In Northeast Regional Bulletin \#493, 3rd ed.; Sims, J.T., Wolf, A., Eds.; Agricultural Experiment Station, University of Delaware: Newark, DE, USA, 2011; pp. 39-47.

13. Cuervo-Parra, J.A.; López-Sanchez, V.; Ramírez-Suero, M.; Ramírez-Lepe, M. Morphological and molecular characterization of Moniliophtora roreri causal agent of frosty pod rot of cocoa tree in Tabasco, México. Plant Pathol. J. 2011, 10, 122-127. [CrossRef]

14. Munsell, A.H. Soil Color Charts. Munsell Color; Macbeth Division of Kollmorgen Instruments Corporation: Baltimore, MA, USA, 1990.

15. Sarria, G.A.; Torres, G.A.; Vélez, D.C.; Rodríguez, J.; Noreña, C.; Varón, F.; Coffey, M.; Elliot, M.; Martínez, G. Caracterización morfológica y molecular de Phytophthora palmivora agente causal de las lesiones iniciales de la pudrición del cogollo (PC) de la palma de aceite en Colombia. Fitopatol. Colomb. 2008, 32, 39-44.

16. Eszergár, D.; Caesar, K.B. Definition of user groups applying Ward's method. Transp. Res. Procedia 2017, 22, 25-34. [CrossRef]

17. Urdaneta, L.M.; Delgado, A.E. Cocoa plant (Theobroma cacao L.), phylloplane Mycobiota identification, at the Carraciolo Parra Olmedo municipality, Merida state, Venezuela. Rev. Fac. Agron. 2007, 24, 47-68.

18. Jaimes, Y.; Gonzalez, C.; Rojas, J.; Cornejo, O.; Mideros, M.F.; Resterpo, S. Geographic differentiation and population genetic structure of Moniliphtora roreri in the principal cocoa production areas in Colombia. Plant Dis. 2016, 100, 1548-1558. [CrossRef]

19. Phillips-Mora, W.; Aime, M.C.; Wilkinson, M.J. Biodiversity and biogeography of the cacao (Theobroma cacao) pathogen Moniliophthora roreri in tropical América. Plant Pathol. 2007, 56, 911-922. [CrossRef]

20. Lozada, B.S.; Herrera, L.; Perea, J.A.; Stashenko, E.; Escobar, P. Efecto in vitro de aceites esenciales de tres especies de Lippia sobre Moniliopthora roreri (Cif Y Par) Evans et al, agente causal de la moniliasis del cacao. Acta Agronómica 2012, 61, 102-110.

21. Santos, H.A.; Figueredo, R.L.; Priminho, P.C.; Gramacho, K.P.; Micheli, F. Activity of polygalacturonases from Moniliophthora perniciosa depends on fungus culture conditions and is enhanced by Theobroma cacao extracts. Physiol. Mol. Plant Pathol. 2013, 83, 40-50. [CrossRef]

22. Mannon, E.G.; Hong, C. Phytophthora: Identifying Species by Morphology and DNA Fingerprints; APS Press: St. Paul, MN, USA, 2008; p. 158, ISBN 978-0-89054-364-1.

23. Aránzazu, H.; Martínez, N.; Valencia, G.; Coronado, R.; Rincón, D. Manejo del Recurso Genético para Incrementar la Producción y la Productividad del Sistema del Cacao en Colombia; Federación Nacional de Cacaoteros: Bogotá, Colombia, 2009; p. 128, ISBN 978-958-9885-833.

24. Jaimes, Y.; Aránzazu, F.; Rodríguez, E.; Martínez, N. Behavior of introduced regional clones of Theobroma cacao toward the infection Moniliophthora roreri in three different regions of Colombia. Agron. Colomb. 2011, 29, 171-178.

25. Ortíz-Rodriguez, O.O.; Naranjo-Merino, C.A.; García-Cáceres, R.G.; Villamizar-G, R.A. Water footprint assessment of the Colombian cocoa production. Rev. Bras. Eng. Agrícola Ambient. 2015, 19, 823-828. [CrossRef]

26. Sulvarán, J.; Sigarroa, A.; Vargas, R. Characterization of cocoa (Theobroma cacao L.) farming systems in the Norte de Santander department and assessment of their sustainability. Rev. Fac. Nac. Agron. Medellin 2014, 67, 7177-7187. [CrossRef]

27. Phillips-Mora, W.; Castillo, J.; Krauss, U.; Rodríguez, E.; Wilkinson, M.J. Evaluation of cacao (Theobroma cacao) clones against seven Colombian isolates of Moniliophthora roreri from pathogenic groups. Plant Pathol. 2005, 54, 483-490. [CrossRef]

(C) 2019 by the authors. Licensee MDPI, Basel, Switzerland. This article is an open access article distributed under the terms and conditions of the Creative Commons Attribution (CC BY) license (http://creativecommons.org/licenses/by/4.0/). 